\title{
URGENSI MANAJEMEN DALAM DAKWAH
}

\author{
Samsinar S. \\ Institut Agama Islam Negeri (IAIN) Bone \\ samsinarakbar@gmail.com
}

\begin{abstract}
Abstrak
Pelaksanaan dakwah harus dirancang dan dikemas dengan baik sehingga menghasilkan suatu efektivitas dan efisiensi dalam dakwah. Oleh karena itu, perlu adanya manajemen yang baik dalam proses pelaksanaan dakwah dimulai dari perencanaan, pengorganisasian, penggerakan, pengendalian, dan evaluasi dakwah. Proses pelaksanaan dakwah harus memiliki strategi, metode dan manajemen yang baik agar menghasilkan dakwah yang berkualitas dan mencapai tujuan dakwah yang telah ditetapkan.
\end{abstract}

Kata Kunci : Manajemen, dakwah

\begin{abstract}
The implementation of da'wah must be designed and packaged properly so as to produce an effectiveness and efficiency in da'wah. Therefore, there needs to be good management in the process of implementing da'wah starting from planning, organizing, mobilizing, controlling, and evaluating da'wah. The process of implementing da'wah must have a good strategy, method and management in order to produce quality da'wah and achieve the stated preach goals.
\end{abstract}

Key Words : Management, da'wah

\section{PENDAHULUAN}

Islam adalah agama dakwah yaitu agama yang selalu mendorong pemeluknya untuk selalu aktif melakukan kegiatan dakwah. ${ }^{1}$ Maju mundurnya umat Islam sangat bergantung dan berkaitan erat dengan kegiatan dakwah yang dilakukannya. ${ }^{2}$ Kegiatan dakwah merupakan kegiatan yang dilakukan oleh dai dengan menyeru kepada kebaikan dan mencegah dari hal yang mungkar dalam rangka mencapai kebahagiaan di dunia dan di akhirat.

Keberhasilan dari pelaksanaan dakwah dapat diukur dari kemampuan masyarakat yang menjadi sasaran atau objek dakwah mampu melaksanakan ajaran agama serta menjauhi hal-hal yang mungkar. Hal ini memerlukan aktivitas untuk mengadakan evaluasi atau memberikan penilaian terhadap materi yang disampaikan oleh dai kepada mad'u dan mad'u mampu memahami dan melaksanakan apa yang disampaikan oleh dai. ${ }^{3}$ Agar pelaksanaan dakwah dapat efektif, maka di lihat dari

\footnotetext{
${ }^{1}$ M. Masykur Amin, Dakwah Islam dan Pesan Moral (Jakarta: Al-Amin Press, 1997), h. 8

${ }^{2}$ Didin Hafinuddin, Dakwah Islam dan Pesan Moral (Cet. III; Jakarta: Gema Insani Press, 1998), h. 76

${ }^{3}$ Rafi'udin, Maman Abdul Djaliel, Prinsip dan Strategi Dakwah, h. 15.
} 
sudut pandang psikologi dakwah, ada beberapa ciri keefektifannya yaitu apabila dakwah memberikan pengertian kepada masyarakat atau mad'u tentang apa yang didakwahkannya, mad'u merasa terhibur oleh dakwah yang diterima, dakwah berhasil meningkatkan hubungan baik antara dai dan mad'u, dakwah dapat mengubah sikap masyarakat, dan dakwah dapat memancing respon mad'u berupa tindakan. ${ }^{4}$ Untuk itu, pelaksanaan dakwah harus dirancang, disusun dan dikemas secara baik sehingga menghasilkan keefektifan dalam menjalankan aktivitas dakwah.

Dengan demikian, dai harus memahami manajemen dalam berdakwah, jika menginginkan dakwahnya berhasil dengan baik. Manajemen dakwah harus dimulai dengan perencanaan yang matang, pengorganisasian, pembiayaan, pelaksanaan, pengawasan dan evaluasi dakwah serta umpan baik dari kegiatan dakwah. Kegiatan ini merupakan fungsi manajemen yang harus dijalankan atau dilakukan oleh dai dalam berdakwah sehingga dapat mencapai tujuan dakwah.

\section{PEMBAHASAN}

\section{Pengertian Manajemen Dakwah}

Secara bahasa, Mochtar Effendy mengemukakan bahwa manajemen berasal dari bahasa Inggris dari kata kerja to manage yang berarti mengurus, memeriksa, dan memimpin. Jadi dilihat dari asal katanya, manajemen berarti pengurusan, pengendalian, memimpin atau membimbing. Dalam bahasa Arab, manajemen diartikan sebagai at-tanzim yaitu suatu tempat untuk menyimpan segala sesuatu dan penempatan segala sesuatu pada tempatnya. ${ }^{5}$

Secara istilah, James A.F.Artoner, manajemen adalah sebuah proses perencanaan, pengorganisasian, pengaturan terhadap para anggota organisasi serta penggunaan seluruh sumber-sumber yang ada secara tepat untuk meraih tujuan organisasi yang sudah diterapkan. Pengertian ini mengindikasikan bahwa ada tanggung jawab yang diemban bagi anggota dalam suatu organisasi untuk menjalankan organisasi tersebut dimulai dari melakukan perencanaan, pengorganisasian, dan pengaturan agar meraih tujuan dalam organisasi.

Selain itu, Robert Kreitner dalam Wahidin Saputra, manajemen adalah sebagai suatu proses kerja melalui orang lain untuk mencapai tujuan organisasi dalam lingkungan yang berubah. Proses ini berpusat pada penggunaan yang efektif dan efisien terhadap penggunaan sumber daya manusia. ${ }^{6}$ Jadi inti dari pengertian ini adalah pembagian kerja dengan memaksimalkan kemampuan manusia agar dapat mencapai tujuan tertentu dalam sebuah organisasi.

Dalam melaksanakan manajemen ada beberapa unsur yang terkait sebagaimana pendapat George R. Terry dalam buku Principles of Management dikutip dalam Wahidin Saputra yaitu planning (perencanaan), organizing (pengorganisasian), Actuiting (penggerakkan), dan Controlling (pengawasan).

Kegiatan apapun yang dilakukan harus dimanage dengan baik dengan memperhatikan unsur-unsur yang terkandung dalam manajemen. Begitu juga dalam melakukan aktivitas dakwah harus dimanage dengan baik agar memperoleh hasil yang diharapkan.

Manajemen dakwah menurut A. Rosyad Shaleh yaitu sebagai proses perencanaan tugas dimulai dari mengelompokkan tugas dan menggerakkannya ke arah pencapaian

\footnotetext{
${ }^{4}$ Faizah dan Lalu Muchsin Effendi, Psikologi Dakwah (Jakarta: Kencana, 2009), h. XV.

${ }^{5}$ Wahidin Saputra, Pengantar Ilmu Dakwah, h. 283.

${ }^{6}$ Wahidin Saputra, Pengantar Ilmu Dakwah, h. 284.
} 
tujuan dakwah. ${ }^{7}$ Inti dari manajemen dakwah adalah suatu pengaturan secara sistematis dan koordinatif dalam kegiatan atau aktivitas dakwah yang dimulai dari sebelum pelaksanaan kegiatan sampai akhir kegiatan dakwah. ${ }^{8}$ Dalam kegiatan ini semua unsur-unsur dakwah harus menjadi perhatian bagi pelaksana dakwah dimulai dari dai itu sendiri, mad'unya, materinya, metode dan medianya, serta efek atau pengaruh yang ditimbulkan dari dakwah tersebut.

\section{Aspek-Aspek dalam Kegiatan Manajemen Dakwah}

Adapun aspek-aspek dalam kegiatan manajemen dakwah yaitu :

\section{a. Aspek perencanaan dakwah}

Perencanaan merupakan pangkal tolak dari suatu aktivitas managerial. Oleh karena itu, perencanaan memiliki peran yang sangat urgen dalam suatu organisasi, sebab ia merupakan dasar dan titik tolak dari aktivitas selanjutnya. Agar proses dakwah dapat memperoleh hasil yang maksimal, maka perencanaan merupakan sebuah keharusan. Setiap sesuatu itu membutuhkan perencanaan, sebagaimana Rasulullah saw. bersabda : "Jika anda ingin mengerjakan suatu pekerjaan, maka pikirkanlah akibatnya, jika pekerjaan itu baik ambillah dan jika pekerjaan itu buruk, maka tinggalkanlah" (HR Ibnu al-Mubarak)

Dalam organisasi dakwah, merencanakan menyangkut merumuskan tujuan organisasi, menetapkan strategi menyeluruh untuk mencapai tujuan dan menyusun hirarki lengkap rencana-rencana untuk mengintegrasikan dan mengkoordinasikan semua aktivitas.

Pada perencanaan dakwah bertujuan untuk menentukan langkah dan program dalam menentukan setiap sasaran, menentukan materi yang akan disampaikan, metode yang digunakan, media, serta dai yang akan menjadi pelaksana dakwah.

Suatu perencanaan dakwah hendaknya memenuhi kriteria yaitu :

1. Meyakini bahwa apa yang akan dilakukan adalah baik, dan landasannya adalah al-Qur'an dan Hadis

2. Pastikan bahwa aktivitas dakwah yang akan dilaksanakan memiliki manfaat yang baik atau memiliki kemaslahatan bagi umat

3. Untuk merencanakan aktivitas dakwah, dai harus memiliki ilmu pengetahuan yang memadai, sehingga dapat melaksanakan dakwahnya sesuai kompetensi ilmunya

4. Dipikirkan dan dianalisis proses dakwahnya serta kelanjutan dari aktivitas dakwah yang akan dilaksanakan

5. Memperkirakan dan memperhitungkan masa depan serta menetapkan tindakan-tindakan dakwah serta penjadwalan waktu, lokasi, biaya, materi, metode, dan media yang akan digunakan.

Proses perencanaan dakwah merupakan tindakan sistematis yang dapat membantu mengidentifikasi cara-cara yang lebih baik untuk mencapai tujuan dakwah.

Dengan melakukan perencanaan dakwah maka akan memberikan manfaat yaitu :

${ }^{7}$ Abd. Rosyad Saleh, Manajemen Dakwah Islam (Jakarta: Bulan Bintang, 1997), h. 123.

${ }^{8}$ Munir dan Wahyu Ilahi, Manajemen Dakwah (Cet. II; Jakarta: Kencana, 2009), h. 36-37. Lihat juga Wahidin Saputra, Pengantar Ilmu Dakwah, h. 287. 
1. Dapat memberikan batasan tujuan dakwah sehingga mampu mengarahkan para dai secara tepat dan maksimal

2. Menghindari penggunaan secara sporadic sumber daya manusia dan benturan aktivitas dakwah yang tumpang tindih

3. Dapat melakukan prediksi dan antisipasi mengenai berbagai problema dan merupakan sebuah persiapan dini untuk memberikan solusi dari setiap problem dakwah

4. Dapat melakukan pengorganisasian dan penghematan waktu dan pengelolaannya secara baik

5. Dapat melakukan pengawasan sesuai dengan ukuran-ukuran objektif

Perencanaan harus didahului dengan penelitian dan persiapan yang matang baik yang menyangkut tenaga sumber daya manusia, metode yang diterapkan dan komponen lainnya dalam berdakwah. Dengan perencanaan ini maka aktivitas dapat berjalan dengan baik, arah dan target dapat dengan mudah dicapai. ${ }^{9}$ Keharusan melakukan perencanaan, sesuai dengan QS. al-Hasyr/59:18, Allah swt. berfirman :

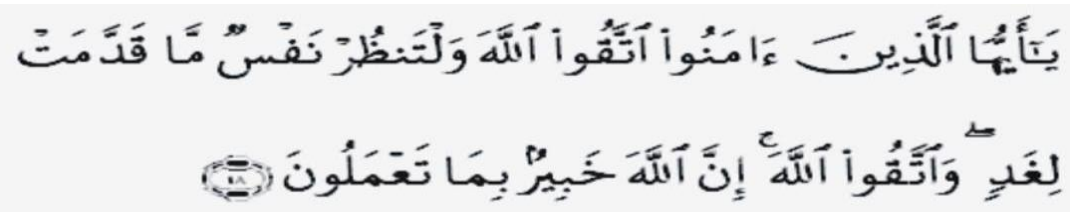

Terjemahnya :

Hai orang-orang yang beriman, bertakwalah kepada Allah dan hendaklah Setiap diri memperhatikan apa yang telah diperbuatnya untuk hari esok (akhirat); dan bertakwalah kepada Allah, Sesungguhnya Allah Maha mengetahui apa yang kamu kerjakan.

Dengan demikian, kegiatan perencanaan dakwah merupakan kunci awal dalam melaksanakan proses dakwah agar memudahkan dai mencapai tujuan dakwah. Oleh karena itu, dakwah harus direncanakan secara matang sehingga memudahkan proses kegiatan dakwah selanjutnya.

\section{b. Aspek pengorganisasian dakwah}

Hani Handoko dalam Hasanuddin mengemukakan bahwa pengorganisasian merupakan proses penyusunan struktur organisasi yang sesuai dengan tujuan organisasi, sumber daya yang dimilikinya. ${ }^{10}$ Pengorganisasian atau dalam istilah agama disebut al-thanzim merupakan wadah atau menekankan pada pekerjaan dapat dilakukan secara rapi, teratur, dan sistematis. Sebagaimana terdapat dalam QS. al-Shaff/61:4 :

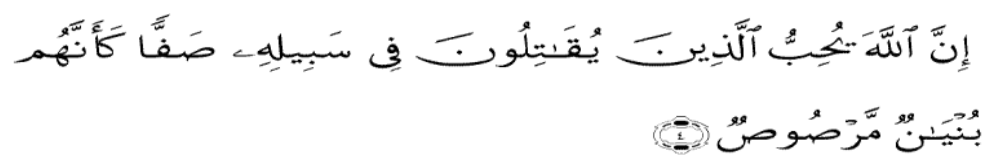

\footnotetext{
2013), h. 9.

${ }^{9}$ Awaluddin Pimay, Manajemen Dakwah: Suatu Pengantar (Cet. I; Yogyakarta: Pustaka Ilmu,

${ }^{10}$ Hasanuddin, Manajemen Dakwah (Jakarta : UIN Jakarta Press, 2015), h. 112.
} 
Terjemahnya :

"Sesungguhnya Allah menyukai orang yang berperang dijalan-Nya dalam barisan yang teratur seakan-akan mereka seperti suatu bangunan yang tersusun kokoh".

Tugas dai selain merencanakan dakwahnya, juga merancang sebuah struktur organisasi yang memungkinkan mereka untuk mengerjakan program dakwah secara efektif dan efisien untuk mencapai sasaran-sasaran dan tujuan-tujuan organisasi.

Organisasi dakwah memiliki tujuan dalam hal membagi kegiatan-kegiatan dakwah menjadi departemen-departemen atau divisi-divisi dan tugas-tugas yang terperinci dan spesifik, membagi kegiatan dakwah serta tanggung jawab yang berkaitan dengan masing-masing jabatan atau tugas dakwah, mengkoordinasikan berbagai tugas organisasi dakwah, mengelompokkan pekerjaan-pekerjaan dakwah ke dalam unit-unit, membangun hubungan di kalangan dai, baik secara individual, kelompok dan departemen, menetapkan garis-garis wewenang formal, mengalokasikan dan memberikan sumber daya organisasi dakwah, serta dapat menyalurkan kegiatan-kegiatan dakwah secara logis dan sistematis. ${ }^{11}$

Organisasi dakwah dapat dirumuskan sebagai rangkaian aktivitas menyusun suatu kerangka yang menjadi wadah dalam melaksanakan kegiatan dakwah melalui pembagian dan pengelompokan pekerjaan yang harus dilaksanakan serta menetapkan dan menyusun jalinan hubungan kerja diantara satuan-satuan organisasi. Pengorganisasian mengandung koordinasi yang mendatangkan keuntungan berupa terpadunya berbagai kemampuan dan keahlian dari pelaksana dakwah dalam satu kerangka kerjasama dakwah yang semuanya diarahkan pada sasaran yang telah ditentukan. ${ }^{12}$

Pengorganisasian dakwah sangat penting, sebab pada proses pengorganisasian ini akan menghasilkan sebuah rumusan struktur organisasi dakwah dan pendelegasian wewenang serta tanggung jawab dalam pelaksanaan dakwah. ${ }^{13}$ Selain itu, keberadaan organisasi dakwah akan mampu melestarikan dan menebarkan nilai-nilai ajaran Islam kepada penerima dakwah melalui penerapan program dakwah. Dengan demikian, peran organisasi dakwah sangat penting dalam mempengaruhi kehidupan sosial umat sehingga membawa perubahan bagi umat dan tercapai kerukunan, kedamaian dan kemaslahatan.

Ada dua hal yang harus diperhatikan dalam pengorganisasian dakwah yaitu desain organisasi dakwah dan struktur organisasi dakwah. Desain organisasi dakwah dapat dilakukan dengan melibatkan keputusan-keputusan dalam melakukan spesialisasi dakwah, departementalisasi, sentralisasi, desentralisasi dan formalisasi dari dakwah. Sedangkan struktur organisasi dakwah berkenaan dengan kerangka formal organisasi dakwah. Dengan kerangka tersebut posisi atau jabatan diberikan tugas pokok masing-masing, dikelompokkan dan dikoordinasikan. Struktur organisasi dakwah ini menjadi sarana untuk membantu pimpinan organisasi dakwah dalam mencapai sasaran.

${ }^{11}$ Wahidin Saputra, Pengantar Ilmu Dakwah (Cet. II; Jakarta: Rajawali Pers, 2012), h. 298.

${ }^{12}$ Hamriani HM, Organisasi dalam Manajemen Dakwah dalam Jurnal Dakwah Tabligh, Vol. 14, No. 2, Desember 2013, h. 239-249. Diakses pada tanggal 4 November 2018.

${ }^{13}$ Hamriani HM, Organisasi dalam Manajemen Dakwah, h.240. 
Hadis Rasulullah saw. yang menjadi landasan dalam melakukan pengorganisasian dakwah yaitu "Dua orang itu lebih baik dari satu, tiga lebih baik dari dua orang dan empat orang lebih baik dari tiga orang, maka berjamaahlah kamu sekalian, sesungguhnya Allah tidak mengumpulkan umat kami kepadanya ada petunjuk." (HR. Bukhari)

Dengan demikian, pengorganisasian dakwah dapat dilakukan dengan cara mengelompokkan unsur-unsur dakwah baik pelaku dakwah maupun penerima dakwah. Dengan pengelompokan ini maka memudahkan dalam pelaksanaan program dakwah.

\section{c. Aspek penggerakan dakwah}

Aspek lain yang harus menjadi perhatian bagi pelaku dakwah sebagai bagian dari manajemen dakwah adalah penggerakan dakwah. Ada beberapa hal yang menjadi perhatian dalam aspek penggerakan dakwah yaitu :

1. Spiritual

Seorang dai harus dapat meningkatkan ketahanan spiritualnya sehingga memperkuat pelaksanaan tugasnya sebagai sebuah amanah yang diembannya. Dai harus memiliki program personal dalam meningkatkan spiritualnya terutama berkaitan dengan ibadah dan muamalah.

2. Pemikiran

Dai harus senantiasa memperkuat pemikirannya melalui berbagai pengamatan dan pengkajian. Oleh karena itu, dai harus mengembangkan dirinya untuk selalu menambah dan meningkatkan wawasan pengetahuannya agar dapat membantu penerima dakwah dalam menghadapi berbagai persoalan yang dihadapinya

3. Material

Dai harus memiliki kemampuan dalam mencari penghidupan bagi dirinya. Oleh karenanya, seorang dai harus memiliki kemampuan interpreneurship agar tidak menjadi beban bagi penerima dakwah.

4. Penguasaan lapangan

Seorang dai harus mengetahui kondisi atau lingkungan dari penerima dakwah. Dengan memahami lingkungan dan kondisi penerima dakwah memudahkan dai dalam menjalankan dakwahnya sehingga dai dapat memprediksi peluang dan kendala yang nantinya dihadapi dalam proses dakwah

5. Gerakan dakwah

Dai harus menguasai gerakan dakwahnya. Dengan penguasaan ini dai dapat mengikuti laju dakwahnya. Pemahaman terhadap gerakan dakwah yang tepat dapat memunculkan sikap dan tindakan dai terhadap apa yang akan dilakukan untuk kepentingan dakwahnya.

Dalam melaksanakan pergerakan dakwah, ada beberapa langkah yang harus ditempuh yaitu pemberian motivasi, pembimbingan, perjalinan hubungan, penyelenggaraan komunikasi, dan pengembangan sumber daya manusia. ${ }^{14}$ Adapun langkah tersebut dapat dijelaskan berikut ini :

1. Pemberian motivasi

\footnotetext{
${ }^{14}$ Wahidin Saputra, Pengantar Ilmu Dakwah, h. 300-308.
} 
Pemberian motivasi merupakan salah satu aktivitas yang harus dilakukan pimpinan dakwah dalam rangka pergerakan dakwah. Pada pelaksanaan dakwah, timbulnya kesediaan untuk melaksanakan tugas-tugas dakwah serta tetap terpeliharanya semangat pengabdian adalah karena adanya dorongan atau motivasi tertentu. Dengan pemberian motivasi tersebut maka dakwah dapat dijalankan dan mendorong para pelaku dakwah untuk mendapatkan keridhaan Allah swt.

2. Pembimbingan

Pembimbingan merupakan tindakan pimpinan yang dapat menjamin terlaksananya tugas-tugas dakwah yang sesuai dengan rencana, kebijaksanaan dan ketentuan-ketentuan, agar apa yang menjadi tujuan dan sasaran dakwah dapat dicapai dengan sebaik-baiknya. Pembimbingan dilakukan dengan memberikan perintah atau petunjuk dan usaha-usaha lainnya yang dapat mempengaruhi dan menetapkan arah tindakan pelaku dakwah. Dengan bimbingan yang tepat dan kesadaran pelaksana dakwah dalam menjalankan perintah terhadap pimpinan dakwah maka usaha dakwah akan berjalan baik dan efektif.

3. Perjalinan hubungan

Salah satu langkah dalam melakukan pergerakan dakwah adalah perjalinan hubungan. Langkah ini bertujuan untuk menjamin terwujudnya harmonisasi dan sinkronisasi usaha-usaha dakwah. Ada beberapa cara yang digunakan dalam langkah ini adalah melakukan musyawarah untuk mencapai mufakat, wawancara dengan para pelaksana dakwah, adanya buku pedoman dan tata kerja serta adanya memo berartai bagi pelaksana dakwah.

4. Penyelenggaraan komunikasi

Dalam melaksanakan pergerakan dakwah dibutuhkan komunikasi yang baik antara pimpinan dan pelaksana dakwah. Komunikasi ini akan berjalan efektif jika memperhatikan beberapa hal yaitu memilih informasi yang akan dikomunikasikan, mengetahui cara-cara menyampaikan informasi, mengenal dengan baik pihak penerima komunikasi, membangkitkan pihak penerima informasi, membangun dan meningkatkan pelaksanaan melalui berbagai kegiatan dakwah untuk mengambangkan kesadaran, kemampuan, keahlian dan keterampilan pelaku dakwah.

5. Pengembangan sumber daya manusia

Langkah terakhir yang dilakukan dalam pergerakan dakwah adalah peningkatan sumber daya manusia. Ada beberapa cara yang dapat ditempuh dalam meningkatkan sumber daya manusia yaitu edukasi atau pendidikan, training atau pelatihan, peningkatan kompetensi dan melakukan pembelajaran.

Kelima langkah di atas harus menjadi perhatian bagi pimpinan dan pelaksana dakwah dalam menjalankan pergerakan dakwahnya sehingga memudahkan tercapainya tujuan dakwah yang telah ditetapkan sebelumnya.

\section{d. Aspek pengendalian dan evaluasi dakwah}

Pengendalian dakwah menjadi aspek penting dalam manajemen dakwah. Kegiatan ini dilakukan untuk perbaikan dakwah dan dijalankan secara berkesinambungan dan dilakukan secara terintegrasi dalam organisasi dakwah. Selain itu, dakwah juga sangat penting untuk dievaluasi. Evaluasi dakwah 
merupakan penilaian terhadap kegiatan dakwah yang telah dilaksanakan untuk meningkatkan pemahaman manajerial dakwah dalam sebuah program formal yang mendorong para pimpinan lembaga dakwah untuk mengamati perilaku anggotanya melalui pengamatan secara mendalam.

Evaluasi dakwah bertujuan untuk mengetahui berhasil tidaknya kegiatan dakwah yang telah dilaksanakan sehingga terukur tingkat keberhasilan atau kegagalan dakwah tersebut, dan pada tahap selanjutnya akan memudahkan memperbaiki kekurangan-kekurangan yang ada. ${ }^{15}$ Evaluasi ini bukan akhir dari kegiatan dakwah tetapi awal dari perbaikan kegiatan dakwah selanjutnya.

\section{Efektivitas Manajemen dalam Dakwah}

Dakwah mensyaratkan sebuah manajemen yang baik guna memastikan dakwah yang disampaikan dapat diterima langsung oleh masyarakat atau mad'u. pengelolaan dakwah yang baik akan menghasilkan perubahan dan meningkatkan efektivitas dakwah. Oleh karena itu, sangat penting untuk memaksimalkan fungsi manajemen agar semua program dan kegiatan suatu organisasi dakwah dapat berjalan sebagaimana mestinya. ${ }^{16}$

Manajemen dakwah merupakan suatu pengelolaan dakwah secara efektif dan efisien melalui suatu organisasi yang terintegrasi yang secara sadar ditetapkan untuk mencapai tujuan. Dalam arti bahwa manajemen dakwah sebagai suatu upaya sadar yang dilakukan oleh suatu lembaga atau organisasi yang direncanakan bersama-sama oleh stakeholder atau yang terlibat dalam pengelolaan organisasi dan sasaran yang menjadi targetnya. Kegiatan ini sangat diperlukan agar aktivitas dakwah dijalankan sesuai dengan model-model manajemen modern.

Ada beberapa langkah yang dapat ditempuh dalam proses manajemen dakwah yaitu :

a. Menentukan Visi dan Misi

Visi dan misi suatu organisasi dakwah harus jelas. Visi dan misi ini harus berpedoman pada ajaran Islam sebagai nilai-nilai universal dalam kegiatan dakwah. Gambaran masa depan dari kegiatan dakwah tertuang dalam visi. Sedangkan misi merupakan penjabaran dari visi. Misi dituangkan dalam bentuk program. Misi inilah yang memberikan petunjuk atau arah kepada manajemen dalam proses penentuan keputusan agar kegiatan dakwah sesuai dengan visi organisasi dan diwujudkan dalam koridor Al-Quran dan Hadis. Untuk memahami visi suatu organisasi maka diperlukan tatanan organisasi. Misi bertujuan untuk memberikan pedoman dalam pengelolaan atau manajemen sesuai dengan kegiatan dakwahnya. Visi dan misi memiliki substansi yang berbeda, namun saling berkaitan. ${ }^{17}$

\footnotetext{
${ }^{15}$ Wahidin Saputra, Pengantar Ilmu Dakwah, h.310.

${ }^{16}$ Andy Dermawan, Manajemen Dakwah Kontemporer di Kawasan Perkampungan : Studi Pada Kelompok Pengajian Asmaul Husna, Potorono, Banguntapan, Bantul DIY dalan Jurnal MD : Membangun Profesionalisme Keilmuan, Edisi Januari-Juni 2016.

${ }^{17}$ Munir dan Ilahi, Manajemen Dakwah, h. 84-85.
} 
Dengan demikian, sebuah organisasi dakwah harus memiliki visi dan misi yang jelas agar dapat menjalankan dan memanaje kegiatan dakwah dengan baik.

b. Menentukan Tujuan

Tujuan adalah dunia cita atau sesuatu yang ingin diwujudkan. Suatu kegiatan yang dilakukan harus berlandaskan pada tujuan. Begitu pula dalam kegiatan dakwah harus memiliki tujuan. Tujuan sangat penting bagi organisasi dakwah. Tujuan merupakan sebuah pernyataan yang memiliki makna yaitu keinginan yang dijadikan pedoman bagi organisasi dakwah dalam memanage dakwah untuk mencapai hasil tertentu. Oleh karena itu, tujuan dalam organisasi dakwah harus jelas dan realis.

c. Rencana Operasional

Dalam organisasi dakwah harus memiliki rencana operasional yaitu memilih rencana terbaik dari alternatif-alternatif yang telah dipersiapkan.

d. Menetapkan urutan kegiatan dan waktu secara rinci bagi rencana yang telah ditetapkan

e. Mengelompokkan anggota dalam organisasi dakwah sesuai dengan bidang masing-masing

f. Mengecek kemajuan rencana yang telah diusulkan

g. Menganalisis data dan mengklasifikasikan data, informasi, dan fakta serta hubungan-hubungannya

h. Menentukan solusi atau alternatif untuk memecahkan masalah yang terjadi

i. Memilih solusi terbaik untuk mencapai hasil yang maksimal. ${ }^{18}$

Dengan mengacu pada langkah di atas, maka organisasi dakwah dapat menjalankan dakwahnya dengan baik sesuai dengan tujuan dakwah yang telah ditetapkan atau sesuai dengan visi dan misi karena dakwah dikelola dengan baik sesuai dengan prosedur yang ada.

\section{PENUTUP}

Dakwah merupakan ajakan kepada orang lain untuk berbuat baik dan melarang untuk berbuat jahat demi untuk keselamatan di dunia dan di akhirat. Dakwah adalah tugas dan kewajiban bagi semua umat Islam. Orang yang berdakwah atau dai harus memiliki kemampuan ilmu agama yang baik dan akhlak yang baik sehingga dapat menjadi teladan bagi masyarakat. Kegiatan dakwah tidak hanya fokus pada proses penyampaiannya saja akan tetapi sebelum pelaksanaan sampai pada akhir kegiatan dakwah. Kegiatan inilah yang disebut dengan kegiatan dalam manajemen dakwah. Kegiatan dakwah harus dirancang, diatur, dikelola dan dikoordinasikan dengan baik oleh dai atau organisasi dakwah. Manajemen dakwah bertujuan dan berguna sebagai penuntun dan pemberi arah dalam pelaksanaan dakwah sehingga dapat diwujudkan

${ }^{18}$ Hasibuan, 2009, h. 112. 
secara profesional dan berkualitas. Fungsi dari manajemen dakwah dimulai dari perencanaan yang baik, pengorganisasian, penggerakan atau pelaksanaan, pengendalian dan evaluasi dakwah. Dalam mengelola dakwah maka banyak komponen yang terlibat mulai dari kemampuan dai atau sumber daya manusia dalam organisasi dakwah, material, dana atau biaya, alat atau media, metode, dan komponen lainnya. Dengan melakukan manajemen dakwah maka akan menghasilkan dakwah yang berkualitas.

\section{DAFTAR PUSTAKA}

Amin, M. Masykur. Dakwah Islam dan Pesan Moral. Jakarta: Al-Amin Press, 1997.

Dermawan, Andy. Manajemen Dakwah Kontemporer di Kawasan Perkampungan : Studi Pada Kelompok Pengajian Asmaul Husna, Potorono, Banguntapan, Bantul DIY dalan Jurnal MD : Membangun Profesionalisme Keilmuan, Edisi Januari-Juni 2016.

Faizah dan Effendi, Lalu Muchsin. Psikologi Dakwah. Jakarta: Kencana, 2009.

Hafinuddin, Didin. Dakwah Islam dan Pesan Moral. Cet. III; Jakarta: Gema Insani Press, 1998.

Hamriani HM. Organisasi dalam Manajemen Dakwah dalam Jurnal Dakwah Tabligh, Vol. 14, No. 2, Desember 2013, h. 239-249. Diakses pada tanggal 4 November 2018.

Hasanuddin. Manajemen Dakwah. Jakarta : UIN Jakarta Press, 2015.

Hasibuan, 2009, h. 112.

Munir dan Ilahi, Wahyu. Manajemen Dakwah. Cet. II; Jakarta: Kencana, 2009.

Pimay, Awaluddin. Manajemen Dakwah: Suatu Pengantar. Cet. I; Yogyakarta: Pustaka Ilmu, 2013.

Rafi'udin, Maman Abdul Djaliel, Prinsip dan Strategi Dakwah, h. 15.

Saleh, Abd. Rosyad. Manajemen Dakwah Islam. Jakarta: Bulan Bintang, 1997.

Saputra, Wahidin. Pengantar Ilmu Dakwah. Cet. II; Jakarta: Rajawali Pers, 2012. 